\title{
Ultrasonic methods and their implementation for evaluating porous materials
}

\author{
A. Petrauskas ${ }^{1}$, D. Petrauskas ${ }^{2}$ \\ 1-Prof. K. Baršauskas Ultrasound Institute, Kaunas University of Technology \\ Studentu st.50,LT-51368Kaunas, Lithuania; E-mail: Algimantas.Petrauskas@ktu.lt \\ 2-Company "Matmuo" \\ Topoliu st.2-24,LT-51370, Kaunas, Lithuania; E-mail: matmuo@matmuo.lt
}

\begin{abstract}
In this article application of direct and indirect ultrasonic methods for evaluating and measuring porous materials are reviewed. Ultrasonic waves, due to their physical properties and wide frequency range can successfully be applied when evaluating the porosity of materials. Ultrasonic methods have many advantages when comparing them with other, non-acoustic measurement methods, which are also briefly reviewed in this article. We examine application of the proposed acoustic echolocation method when evaluating porous materials directly and indirectly. The possibilities to apply Lamb waves for evaluation of porous structures are also examined. The application of ultrasonic echolocation measurement method to evaluate porous structures indirectly is presented in depth, along with the process description and various possible implementations. The basic principle along with advantages and shortcomings of such methods are explained. Physical-mechanical properties of porous materials are also described, along with mathematical equations, which are necessary for their theoretical analysis. The ability to determine porosity of various materials is necessary to insure the quality of the final product. We also present a working real-world system, which implements an indirect ultrasonic porosity evaluation method. For indirect porosity determination, we use a very accurate ultrasonic echolocation-based distance meter. Block diagram for such unit is presented. The most important component in the acoustic porosity evaluation system is the electro-acoustic transducer. We describe the most suitable transducers for use in this case, along with acoustic antennas constructed using such transducers. Antennas, designed for measurements in air, consist of transducers vibrating in a flexural mode, which give the best possibility to match acoustic impedances between air and the transducer. Specific type of transducers for acoustic antennas is described, along with their schematic diagrams. The necessary expressions for calculating radiations patterns are also supplied. Schematic diagrams of actual antennas, along with their directivity patterns are presented. A method for eliminating peripheral radiation of these antennas is also described.

Keywords: porous material, physical-mechanical properties, evaluation of porous materials, acoustic echolocation method, direct and indirect acoustic measurement methods, Lamb wave, ultrasound, echolocation, acoustic level meter for liquids, acoustic antenna, flexural vibration, radiation pattern.
\end{abstract}

\section{Introduction}

Porous materials are most frequently encountered in food industry, cosmetics, furniture production, thermoinsulation materials, filters, etc. Depending on the application, various quality requirements exist.

To determine the porosity of materials, various methods are used, including mechanical, optical, electrical, photographic, radio isotopic, X-ray, infrared and spectrometric methods [1-9]. We will briefly look into some of these methods.

Today, porosity is determined by using a standardized mechanical method. This method is based on measuring the quantity of liquid, which is absorbed by the pores of a porous material. To determine the porosity, the sample of a porous material is submersed in liquid and is then taken out after a given time. Before and after submersion the sample is weighed. By analyzing the weight difference and minding the volume of the sample, porosity is determined. This method requires accurateness and responsibility from an operator. When the sample is taken out of water, some liquid is being lost, or the sample can physically break up. The mechanical method has a drawback because it is nontechnological and cannot be applied in a continuous production process. This method is destructive and produces little information. It does not determine in real time the quantity of water penetrating into the sample. In addition, it does not supply any information about the structure and defects of the surface of the sample. This is very important when developing technology for high quality products [1-3].
The optical method enables us to evaluate only the surface of a porous material, but does not provide information about the inner structure. The sensitive radio isotopic method is not desirable, because there is a hazard to personal health and it has a negative influence on the porous materials, which are analyzed using this method. The electrical method has influence on the chemical composition of the porous material. Our experimental testing indicates that when electric current is passing through the porous material, conductive channels are being created. Due to these channels, large inaccuracies are present.

The spectrometric measurement methods [10-24] create a separate and interesting group of measurement methods. These methods were developed using electromagnetic and acoustic waves as carriers of information. From the spectrum of electromagnetic waves, infrared waves are used most frequently. Measurement methods from this group have a high accuracy. The measurements of parameters of wave processes are widely applied in practice. Duration, frequency, amplitude and phase are easily measurable parameters of wave processes.

Most frequently measured parameters in technical measurements are: the time interval between signals [2533], monochromatic and spectral measurements of signal's amplitude [13-16, 27].

Out of previously mentioned methods, the spectrometric method is the most complicated. It is difficult to apply this method for manufacturing processes in an environment with many disturbances. Therefore, the 
most suitable way for measuring porosity in such environment is to use a method based on measuring the time interval between signals or, in other words, method based on measuring ultrasound propagation velocity through materials. In addition, the method based on measuring signal's amplitude or, in other words, method based on measuring ultrasound attenuation through materials, can successfully be applied. These methods provide the best results when a frequency from a wide range is chosen. The velocity of acoustic waves in various materials is not very high. For example, sound velocity in gas is around $300 \mathrm{~m} / \mathrm{s}$, in liquids - around $1500 \mathrm{~m} / \mathrm{s}$, and in solid materials - around $5000 \mathrm{~m} / \mathrm{s}$. Velocity of acoustic waves is within range of $1000-2000 \mathrm{~m} / \mathrm{s}$ for most of the porous structures. Such a low velocity can easily be measured with a high accuracy.

Today there is a live interest in acoustic measurement methods [34-70]. These methods can be direct [34-62] or indirect [62-70]. The most widely used direct method is when parameter changes of ultrasonic signal are measured after the signal has penetrated the porous material. Due to the complex propagation of ultrasonic signals, direct methods are rarely used in practice.

In addition, the direct method mentioned earlier can be combined with an acoustic echolocation method [34-70]. In this case, the ratio of reflected signal's parameters and transmitted signal's parameters is measured. Due to the properties of ultrasonic wave propagation, their application for evaluating porous materials is promising. When the optimal frequency of ultrasonic waves is chosen, structures composed of various particle sizes can be analyzed. For porous materials, the best results are obtained when using lower frequency ultrasonic waves $[41,51,53,54]$.

To determine the density of porous materials, which are placed in thin-walled containers, Lamb waves can be used among other acoustic measurement methods [33].

One of the most critical components, used in an acoustic porosity evaluation system, is the electro-acoustic transducer (antenna). The complexity of the measurement device along with the measurement accuracy greatly depends on the parameters of the electro-acoustic transducer. In the case when optimal electrical signals together with a non-distorting acoustic channel are used in a measurement device, one can expect the quality and reliability of measurement data to be sufficiently high. Therefore, the electro-acoustic transducer used in a measurement system should be efficient, broadband and with a required radiation pattern.

We will overview the physical parameters of porous materials and the dependency of these parameters on each other. Additionally, we will overview direct and indirect ultrasonic methods and their implementation for porosity evaluation.

We will also present some practical calculations and parameters for real-world electro-acoustic transducer design.

\section{Physical-mechanical parameters of porous materials}

By the origin of their pores, porous materials can be separated into four main categories $[4,6,33]$ : a) when pores are separated from each other by layers of material;

b) when pores are interconnected;

c) when the material is composed of fibers;

d) when the separating material is composed of stripes.

The main physical-mechanical parameters of porous materials are dispersion, pattern of pores (repeatability) and density. Porous materials are described by the size of their pores and uniformity. The separating layers between pores can be thinner or thicker. These layers can also be elastic or solid. The pattern of a porous material is inversely proportional to a density. The pattern describes the volume ratio of pores and separating layers. The density of a porous material is given by [33]:

$$
\rho_{P}=\left(m_{g}+m_{l}\right) / V_{P}=\left(\rho_{g} V_{g}+\rho_{l} V_{l}\right) / V_{P},
$$

where $m_{g}$ and $m_{l}$ are the masses of gas and of separating layer respectively; $\rho_{g}$ and $\rho_{l}$ is the density of gas and of separating layer respectively; $V_{P}, V_{g}, V_{l}$ are the volumes of porous material, of gas and of separating layer respectively.

Because the density of a separating layer is more than 1000 times higher than the density of gas $(n>1000)$, then

$$
\rho_{P} \approx \rho_{l} V_{l} / V_{P}=\rho_{l} / n,
$$

where $n$ is the pattern of porous material and

$$
n=V_{P} / V_{g} \text {. }
$$

The simplest way to determine the density of porous materials is to use a direct measurement of volume and mass.

In this case the density of porous materials is given by:

$$
\rho_{P}=\left(\rho_{l} V_{l}\right) / V_{P}=m_{l} / V_{P} \text {. }
$$

The pattern $n$ of porous materials can be determined using an indirect electrical measurement method [33]:

$$
n=X_{l} /\left(X_{P} B\right),
$$

where $X_{l}$ and $X_{p}$ are the specific electrical conductivities of separating layer and porous material respectively; $B=1.5 \ldots 3$ is the coefficient of a porous material.

The pattern of a porous material can also be determined using an indirect radio isotopic method [33]:

$$
n=\rho_{l} / \rho_{P}=\left[\ln \left(N_{0} / N_{l}\right)\right] /\left[\ln \left(N_{0} / N_{P}\right)\right],
$$

where $N_{0}, N_{P}, N_{l}$ are the pulse counts through gas, porous material and separating layer respectively.

Porous materials are also characterized by the size of their pores. One of the direct methods for evaluating their size is photography [33]. By using this method, it is possible to obtain information about the diameter and shape of pores, and about the width of the separating layer. The pores are photographed in direct or reflected light by magnifying them from 10 to 100 times.

It needs to be noted that various corrective multipliers need to be added to most of the expressions used for calculating physical-mechanical properties of porous materials. The corrective multipliers depend on the chosen measurement method. These expressions are most suitable when evaluation is being done in laboratory conditions, but cannot be used when designing automated systems used for manufacturing porous products. 
Best suitable methods for designing automated control systems are method based on measuring ultrasound velocity through materials $[10,15,16-20,31,33]$ and method based on measuring ultrasound attenuation [27, 30, $31,33,36-39,41,42]$ in materials. Both of these methods require a very short time to get the final result. In addition, they do not require special sample preparation or any kind of sample destruction. They can be used for real-time process control, what makes them even more attractive.

\section{Direct acoustic methods for evaluating parameters of porous materials}

A direct ultrasonic measurement method is when parameter changes of ultrasonic signal are measured before entering and after the signal has penetrated the porous material $[10,15,16-20,31,33,36-39]$. The porosity (density) is then determined by analyzing the ratio of these signals. If the porosity of the material is high and the pores are quite large, then the parameter changes of ultrasonic signals are smaller and difficult to measure. When comparing samples of material, their thickness should be as equal as possible. In this case, the amplitude of the signal, which has propagated through the porous material, is calculated from expression [33]:

$$
A_{\text {out }}=K_{0} A_{\text {in }} e^{-\alpha \rho_{P} l_{P}},
$$

where $A_{\text {in }}$ and $A_{\text {out }}$ are the amplitudes of the transmitted and the received signals respectively; $K_{0}$ is the corrective multiplier dependent on a measurement environment; $\alpha$ is the attenuation of ultrasound in the porous material; $l_{P}$ is the thickness of sample.

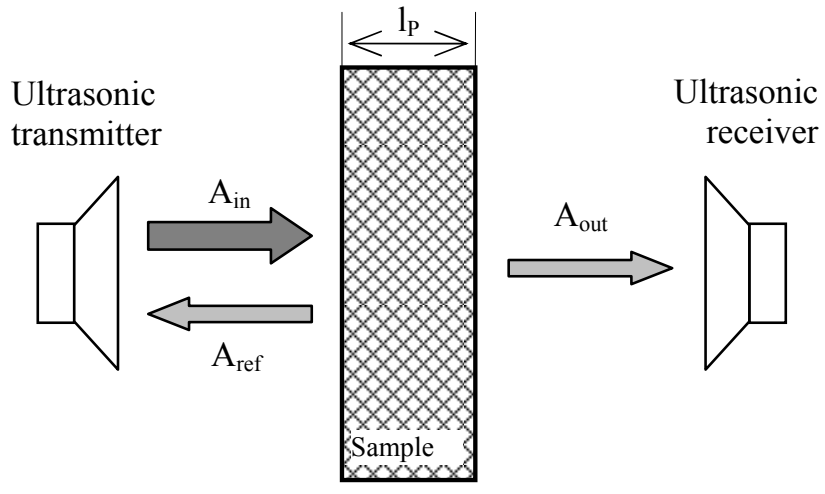

Fig.1. Diagram of a porous material evaluation by using a direct ultrasonic method, where $A_{\text {in }}, A_{\text {out }}$ and $A_{\text {ref }}$ - amplitudes of transmitted, received and reflected signals respectively, $l_{P}-$ thickness of the sample

This method can be improved by measuring additionally the amplitudes of signal, which were reflected of the porous material. For example, when the frequency by the signal is $17.20 \mathrm{kHz}$, the density $\rho_{P}\left(\mathrm{~g} / \mathrm{cm}^{3}\right)$ of the porous material can be calculated from expression [33]:

$$
\rho_{P}=\ln \left(A_{\text {ref }} /\left(3.422 \cdot A_{\text {out }}\right)\right) / 15.379,
$$

where $A_{\text {ref }}$ is the amplitude of reflected signal.

When evaluating porous materials using a direct acoustic method in a low frequency range, it is recommended to use a measurement scheme, presented in Fig. 2. This scheme enables to avoid the emerging "standing" waves in the acoustic measurement system

between the ultrasonic transmitter and the measurement sample. These "standing" (multiply reflected) waves negatively influence the measurement results, because the amplitude of the reflected wave adds to the amplitude of the transmitted wave. This measurement scheme (Fig. 2) is also well suitable to use with higher measurement frequencies.
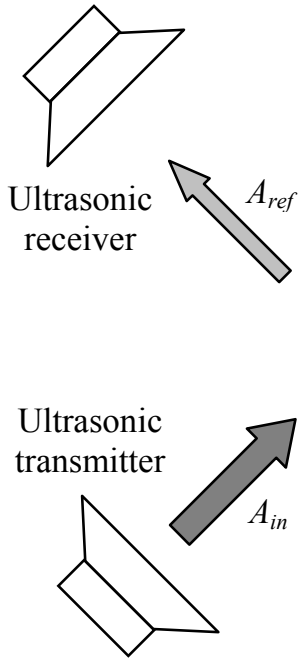

Fig.2. Diagram of porous material evaluation by using a direct ultrasonic measurement method, where $A_{\text {in }}, A_{\text {out }}$ and $A_{\text {ref }}-$ amplitudes of transmitted, received and reflected signals respectively, $l_{P}$ - thickness of the sample

These non-destructive evaluation methods of porous materials can be successfully implemented in practice when designing systems for operation in a continuous production process.

\section{Indirect acoustic methods for evaluating parameters of porous materials}

The indirect measurement methods [63-70] are based on the property of a porous material to absorb liquid. Some time needs to pass until air in the pores is completely displaced by liquid. After sample submersion, the level of liquid begins to change in the measurement vessel. The rate of this change depends on the material's porosity. Among other methods, the ultrasonic echolocation method can be used to measure the change in the level of the liquid. The obtained results, when using this method to measure porosity of various materials, were described by us in [33, 63-70].

The measurement vessel is mounted on a hard and solid support. The electro-acoustic unit of an ultrasonic echolocation level meter is also mounted on the same support above the measurement vessel. This way the distance between the electro acoustic unit and the bottom of the measurement vessel remains constant.

At first, the measurement vessel is filled with water and the water level $h_{l}$ is measured (Fig. 3. a).

Then a sample of a porous material is submersed in the water. The increase in a water level in the measurement vessel is proportional to the volume of the sample. The suddenly risen water level $h_{2}$ is measured with the level meter (Fig. 3. b)). Given that the walls of the measurement vessel are vertical, the volume of the porous material is: 


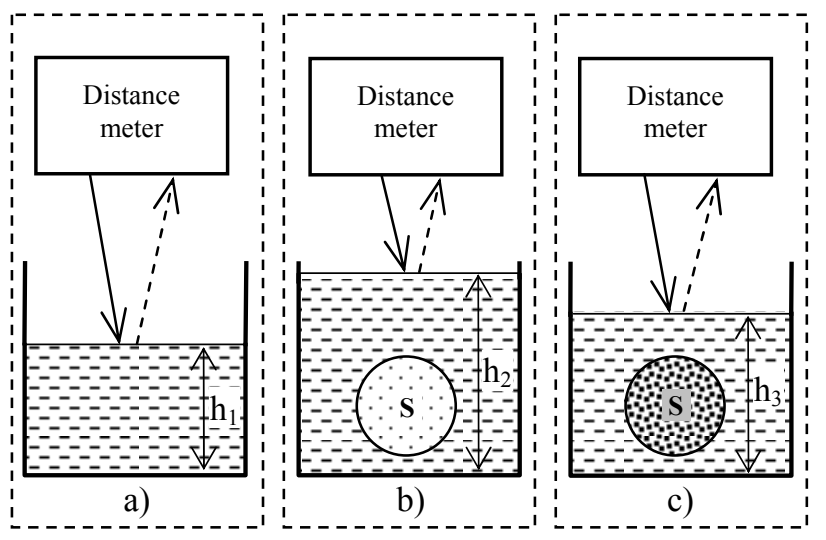

Fig.3. Stages of the porosity evaluation process using acoustic echolocation

$$
V_{P}=\left(h_{2}-h_{1}\right) \cdot S \text {, }
$$

where $S$ is the area of the water's surface.

From the instant of submersing the sample, the falling water level is being constantly recorded until it reaches the lowest level $h_{3}$ (Fig. $3 \mathrm{c}$ )). When the level reaches $h_{3}$, the process ends and the water level remains constant

The water level is falling, because it is penetrating into the pores of the sample, replacing air in the process. The penetration rate of the water is directly proportional to the porosity of the sample.

The changes of the water level are presented in Fig. 4.

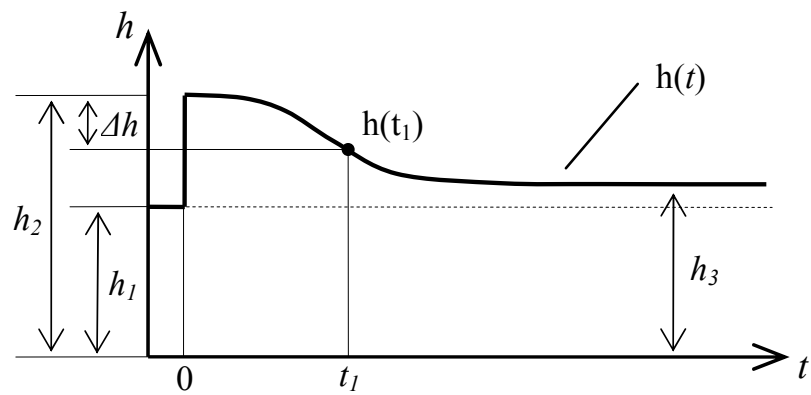

Fig.4. Changes of the water level in the measurement vessel

After a chosen time $t_{l}$, the water level recedes by:

$$
\Delta h=h_{2}-h\left(t_{1}\right) \text {, }
$$

where $\mathrm{h}\left(t_{l}\right)$ is water level at the moment $t_{l}$.

In general, $\Delta h=h(t)$ is a function of water level change in time. The derivative $d h / d t$ is the penetration rate of water. This rate, at a chosen moment, is proportional to the porosity of the sample. is:

The volume of water, which has penetrated the sample,

$$
V_{g}=\left(h_{2}-h_{3}\right) \cdot S \text {, }
$$

where $h_{3}$ is the final level of water, after the gas in the pores of the sample was completely displaced by water.

The value $V_{g}$ shows the amount of gas, which was present in the pores of the sample before submersion. Keeping that in mind, the pattern of the sample's pores, according to expressions (3), (10) and (11), is calculated from expression:

$$
n=V_{p} / V_{g}=\left(h_{2}-h_{1}\right) /\left(h_{2}-h_{3}\right) .
$$

If the porous material has a surface layer with little or no defects, then the water penetrates it slowly, and the decrease in water level $h$ is slow. When the surface layer disintegrates, the penetration rate increases, and the derivative $d h / d t$ only depends on the porosity of the porous material and the properties of the separating layer between pores.

It needs to be noted that for some porous materials, the separating layers between pores can melt or swell. Therefore, the properties of the porous material also influence the dynamic of water penetration $(d h / d t)$. This information can be used to correct the manufacturing process of products made of porous materials.

The absorption process can also be described mathematically.

When investigating liquid absorption into a sample, as the first step we assumed that it is a homogeneous cylindrical object. Rate of liquid absorption depends on the area of a moistened surface. We also assume that the penetration rate is greater in the parts where the porosity greater. If we take a cylinder of radius $r_{0}$ and the unit length of pivot, then the volume of the absorbed liquid depends on the radius of the cylindrical moistened volume:

$$
V_{S}\left(t, r_{0}\right)=\pi v_{d} t\left(2 r_{0}-v_{d} t\right) .
$$

where $v_{d}$ is the penetration rate; the time is $t \leq r_{0} / v_{d}$.

If the cylindrical sample is not homogeneous and its porosity changes with a depth in the cylinder, we can assume several dependencies of porosity distribution along the cylinder radius $r$.

When the porosity increases with the depth, the penetration rate changes according to equation

$$
v_{d}(r)=v_{d 1} \frac{r_{0}-r}{r_{0}}+v_{d p},
$$

where $v_{d p}$ is the penetration rate on the surface of cylinder, $v_{d l}$ is the decrease of penetration rate with radius. The absorbed amount of liquid in this case is

$$
\begin{aligned}
& V_{s t}=\pi\left(v_{d p} t+\frac{v_{d p} v_{d 1} t^{2}}{r_{0}-v_{d 1} t}\right) \times \\
& \times\left[2 r_{0}-\left(v_{d p} t+\frac{v_{d p} v_{d 1} t^{2}}{r_{0}-v_{d 1} t}\right)\right]
\end{aligned} .
$$

In real-world conditions, porosity with a depth may change nonlinearly. We assumed the square root law of dependence of penetration rate with a depth

$$
v_{d s}(r)=v_{d 2} \sqrt{\frac{r_{0}-r}{r_{0}}}+v_{d p},
$$

where $v_{d 2}$ is increase of the penetration rate. The volume of the absorbed liquid is given by:

$$
\begin{aligned}
& V_{s s}=\pi t\left[\frac{v_{d 2}}{2 r_{0}}\left(v_{d 2} t \pm \sqrt{\left(v_{d 2} t\right)^{2}+4 v_{d p} t r_{0}}\right)+v_{d p}\right] \times \\
& {\left[2 r_{0}-t\left[\frac{v_{d 2}}{2 r_{0}}\left(v_{d 2} t \pm \sqrt{\left(v_{d 2} t\right)^{2}+4 v_{d p} t r_{0}}\right)+v_{d p}\right]\right.}
\end{aligned}
$$


These penetration rate dependencies were modeled and the dependencies of the absorbed liquid volumes versus time were obtained. Although the amount of the absorbed liquid monotonously increases in all three cases, the behavior of derivatives differs noticeably. In case of a homogenous structure, the rate of change of the absorbed liquid volume decreases with time. If penetration rate increases with a depth, the change of the volume is rather uniform. The rate of volume changes decreases with the time nonlinearly when the penetration rate increases with a depth according to the square root law.

When the porosity decreases with a depth, the penetration rate also decreases as

$$
v_{d}(r)=v_{d l} r+v_{d 0} .
$$

If we decide that the rate increases with the radius as a square root then the equation is given by

$$
v_{d s}=\sqrt{v_{d 2}(r)}+v_{d 0}
$$

where $v_{d 0}$ is penetration rate in the center of the cylinder.

The modeling process in this case is similar to the previous cases [33].

\section{Other indirect acoustic methods for evaluating parameters of porous materials}

To determine the porosity of porous materials, Lamb waves are an interesting option. Excitation and propagation of Lamb waves in elastic plates, placed in gas and liquid environments, is thoroughly researched in scientific papers $[10,71-78]$. We think that propagation of Lamb waves in plates was not yet researched, in case when a porous material is loaded only on one surface of a plate.

We propose an improved measurement method (Fig.5) for porous materials based on Lamb wave measurements. To improve the acoustic contact between the sample and the plate, a weight should be placed on the top of a sample. The weight should be as heavy as possible, but should not change the physical-mechanical properties of the sample.

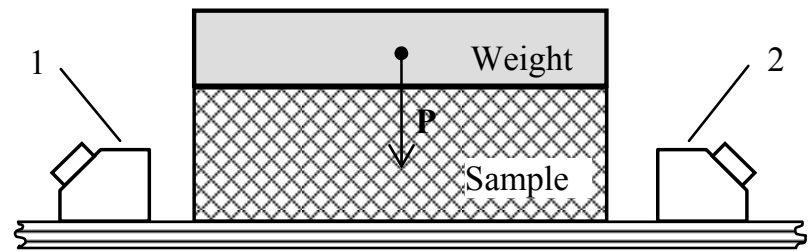

Fig.5. Measuring diagram for porous materials by using Lamb waves; 1 - Lamb wave transmitter, 2 - Lamb wave receiver

Regarding publications [10, 71-73], we propose to use an asymmetrical $A_{0}$ mode Lamb wave. The attenuation for this wave is directly proportional to the density of porous material and inversely proportional to the thickness of the plate. In practice, the thickness of the plate is known. Therefore, the attenuation depends only on the density of a porous material. In practice, it is advisable to use thin plates.
The diagram of another indirect measurement method is presented in Fig. 6.

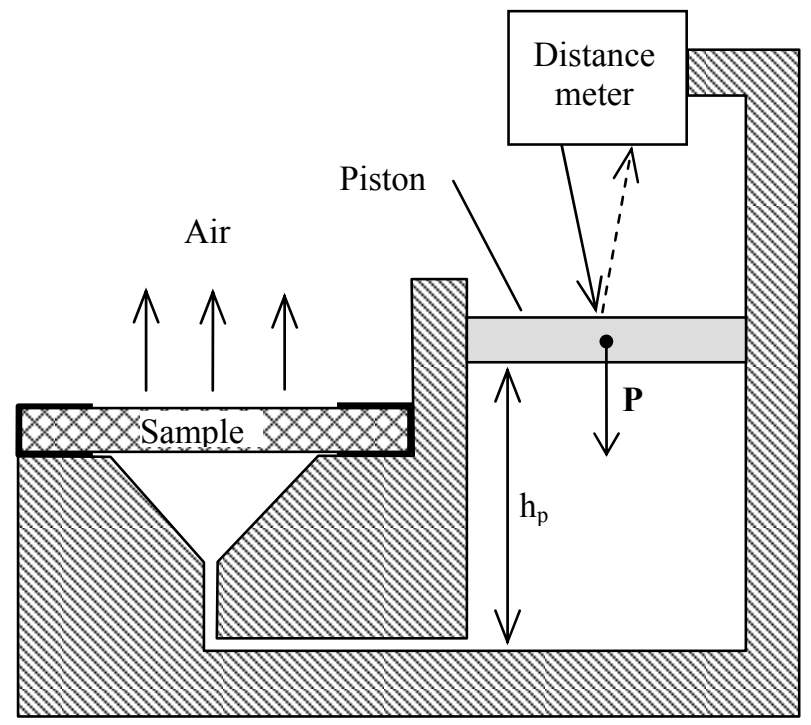

Fig.6. Diagram of an indirect measurement method for determining the porosity of porous materials by using compressed air and acoustic distance meter

In the measurement unit, the piston creates pressure $\mathrm{P}$, which forces the volume of air through the porous material (sample) of a specified thickness:

$$
V_{g}=h_{p 0} \cdot S
$$

where $h_{p}$ is the height of the gas chamber; $S$ is the surface area of the piston.

The time, during which the piston reaches the bottom of the chamber, along with the speed of piston's descent, are measured (Fig. 7).

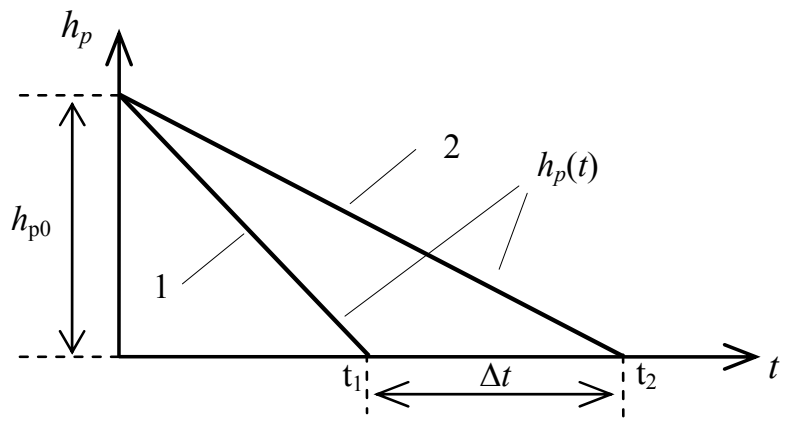

Fig.7. Diagram of the piston's descent; 1 - the descent when the sample is more porous; 2 - the descent when the sample is less porous

The time $t$ is inversely proportional to the porosity of the sample. By comparing the piston's descent times for various porous materials, the differences of their porosity are determined. The speed of the piston's descent $\left(d h_{p} / d t\right)$ is used to determine the size of the pores of the porous material, pore pattern and the thickness of separating layers between pores. This measurement method can also be applied when evaluating loose materials (grains).

In Fig. 8 we present another variation of an indirect porosity evaluation method. 


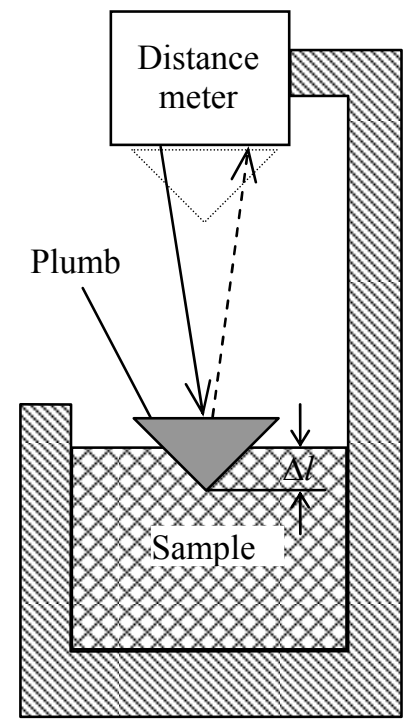

Fig.8. Diagram of an indirect measurement method for determining the porosity of porous materials by measuring the penetration depth of a plumb into a porous material

The plumb is released from the same height and freefalls until it penetrates into the sample. The higher the penetration depth, the higher the porosity of the sample.

This method is only suitable for evaluating the porosity differences between different samples of a porous material of the same nature.

\section{Practical implementation of an indirect acoustic method for evaluating parameters of porous materials}

By applying the principles of echolocation, we succeeded to develop a complex mechanical method for evaluating porous materials [63-70]. We measured the quantity of the absorbed liquid without taking the sample out of the measurement vessel. In addition, we determined the quantity of liquid penetrating into the sample in a real time. To achieve this, we measured the change of liquid's level in the measurement vessel. For this purpose, a highly accurate distance meter for liquids was used.

After the sample is submersed, the level of liquid begins to change in the measurement vessel. The velocity of this change depends on the material's porosity. Among other methods, the ultrasonic echolocation method can be used to measure the change of liquid's level. The obtained results, when using this method to measure porosity of various materials, were described by us in [63-68].

To investigate the quality of porous materials, we proposed to use a non-contact ultrasonic method [63]. The later is based on determining the swell of porous materials in various liquids. Further investigations to increase the accuracy of measurement results in the swelling process of porous materials in various liquids were performed using a special measurement vessel [63]. This vessel has an improved design of the sample-keeping container screen. It enables us to avoid the negative influence of gas bubbles, which are raising from sample, on the measurement results. Additionally, we make it possible to transfer the information from the measurement equipment to a PC for automatic measurements and processing.
A schematic diagram of a porosity determination unit is presented in Fig. 9. The sample is placed in the evaluation measurement vessel. This vessel is submersed into the liquid, which is in the base of the measurement vessel. The liquid then penetrates into the sample of a porous material.

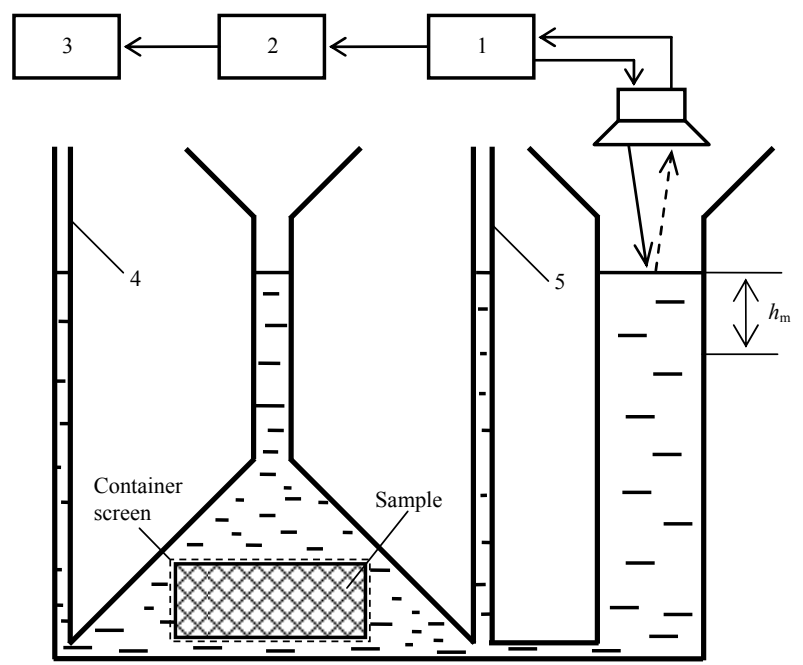

Fig.9. Porosity evaluation diagram using an acoustic echolocation method: 1 - acoustic distance meter for liquids, 2 - interface, 3 - PC, 4 - evaluation vessel with the measurement sample, 5 base vessel with liquid

From the instant of the sample's submersion, the receding water level is being constantly recorded until it reaches $h_{m}$ (Fig. 9). The water level is falling, because it is penetrating into the pores of the sample, replacing air in the process. The penetration rate of the water is directly proportional to the porosity of the sample [33]. During the first instant of submersion, porous materials with a defectfree surface layer absorb liquid very slowly and the absorbed quantity of water is very low (up to $10 \mathrm{~mm}^{3}$ ). Because of that, the level of liquid in a measurement vessel changes very slowly. To detect such low changes in the level of liquid (corresponding to the volume of $1 \mathrm{~mm}^{3}$ ), a very precise ultrasonic acoustic distance meter is required. The level meter must be able to measure the distance in the interval of 1 to $40 \mathrm{~mm}$. The absolute error of the unit should be no more than 5 microns, when the temperature is $20^{\circ} \mathrm{C}$.

Such accuracy is achieved, when using a non-contact echolocation-based acoustic distance meter [79, 80].

Acoustic (ultrasonic) echolocation-based meters are widely applied for various distance measurements $[10,33$, $63-70,79,80]$. The operating principle of such meters is based on measuring the duration of measurement signal's propagation to the object and back. Many of such meters use pulse measurement signals.

When measuring in a broad temperature range, measurement errors, which occur due to the dependence of the acoustic measurement signal's velocity on temperature $[74,79,80]$ need to be determined and compensated.

When analyzing the influence of a particular echolocation-based meter on a measurement accuracy, choice of a measurement system (layout) is important. The measurement system can be with two electro-acoustic 
sensors, one of which transmits and another receives the measurement signals.

In Fig. 10 we present a block diagram of a twochannel measurement device [79], consisting of available electronic components. In this case, the second measurement channel is used to eliminate the influence of air parameter changes on measurement results.

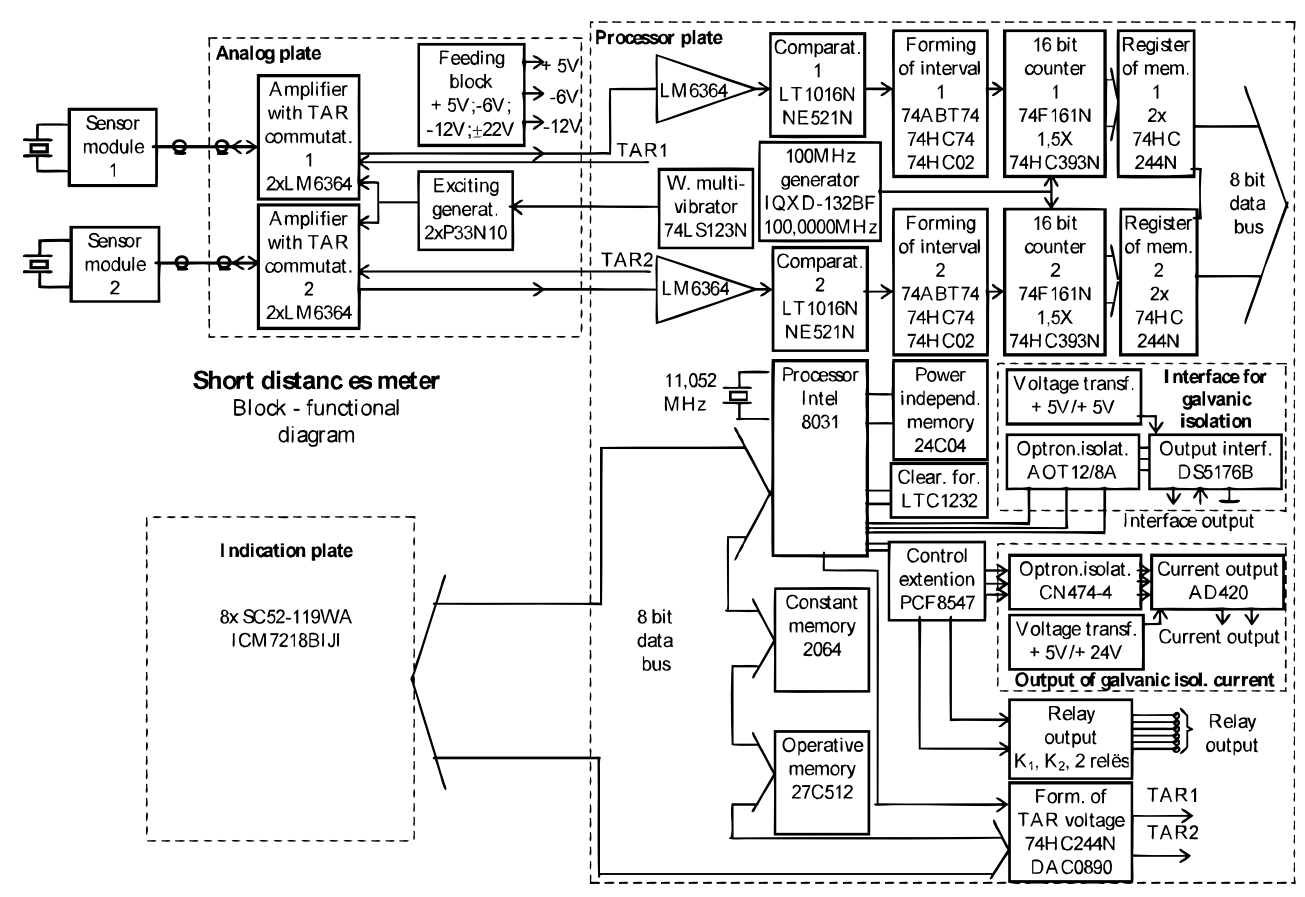

Fig.10. Block diagram of a two-channel distance measurement device for liquids

The second measurement channel of the meter is used as a calibrated channel for determining the exact velocity of sound. The transducer frequency is in $0.8 \ldots 2 \mathrm{MHz}$ range. The transmitters are excited by one half-period electric pulse. The detection circuit for determining zero crossing is used in the receiving channel of measurement signals. This way the obtained measurement accuracy is the same as of the phase method [79]. The obtained time interval, proportional to the measured distance, is filled by $100 \mathrm{MHz}$ marks. These marks are counted by a counter and processed by the processor. The processor performs the primary processing of measurement information (eliminating the changes of ultrasound velocity, calculating average results, etc.).

The meter may be connected to the PC through the interface RS485. The meter also has and LCD panel showing two rows of four-figure results. The maximal measurement error is $0.02 \mathrm{~mm}$. The error arises because of the delays and noises in the electronic circuits and due to the instability of the threshold level of the electronic comparator [79]. Therefore, the signal delay time fluctuates. This instability was reduced by averaging the results of measurement. The errors arising due to changes in temperature, composition, humidity and air pressure in the acoustic measurement channel were eliminated by using the additional calibrated length channel for determination of exact sound velocity. The number of measurement channels can be increased if required.

\section{Acoustic antennas for devices using a direct ultrasonic porosity evaluation method}

To implement practically direct acoustic porosity evaluation methods, we propose to use ultrasonic transducers operating in a flexural vibration mode.

At present times piezoelectric ceramic transducers in longitudinal vibration with matching layers and transducers in flexural vibration are both used in a gas environment [81-99]. Using transducers in a flexural vibration gives the best possibility to match acoustic impedances of air and the transducer, because flexural transducers have a sufficiently low acoustic impedance. Such transducers have a solid radiating surface and therefore are resistant to the effects of the gas environment. Because of this, the application of these transducers in gas environments is very promising and is currently being widely researched.

Alongside various transducer designs with a flexural vibration, a piezoelectric ceramic rectangular thin-plate transducer in a flexural vibration can be used [81-98]. It is promising to use this type of transducer to develop various measurement applications in a gas environment. As will be mentioned below, the required radiation patterns of those rectangular transducers can be easily obtained.

The required radiation patterns are obtained when nodal lines of vibrations on the surface of the rectangular transducer are straight and parallel to one another [88-92]. 
In this case, the transducer's radiation in a plane perpendicular to the surface of the transducer and parallel to the nodal lines of vibrations is the same as an acoustic field generated by an oscillating piston. In a perpendicular plane, if flexural transducer is flat, the transducer reveals a two-leaf radiation pattern and the inclination angle $\alpha$ between the surface of the transducer and a plane, perpendicular to the direction of radiation. This angle depends on a ratio of acoustic wavelength in transducer and in air $[88,89]$ :

$$
\alpha_{1,2}= \pm \arcsin \frac{k_{\delta} \lambda_{a}}{2 l}
$$

where $\alpha$ is the angle between the surface of the transducer and a plane, perpendicular to the direction of radiation; $\lambda_{a}$ is the acoustic wavelength in air; $k_{\delta}$ is the number of nodal lines in a transducer; $l$ is the length of a transducer in the direction of flexural vibrations.

Various authors propose a variety of designs for such transducers [88-99].

In our opinion, it is convenient in practice to use transducers when flexural vibrations are excited in them by transversal or longitudinal displacement. It is preferred that these displacements should be distributed on the entire surface of the transducer. When exciting flexural vibrations in this way, the piezoelectric ceramic transducer has a high efficiency, comparatively small dimensions and a low weight.

We propose a design of the unidirectional acoustic antenna, consisting of an array of four such transducers. The schematic diagram of such antenna is presented in Fig. 11.

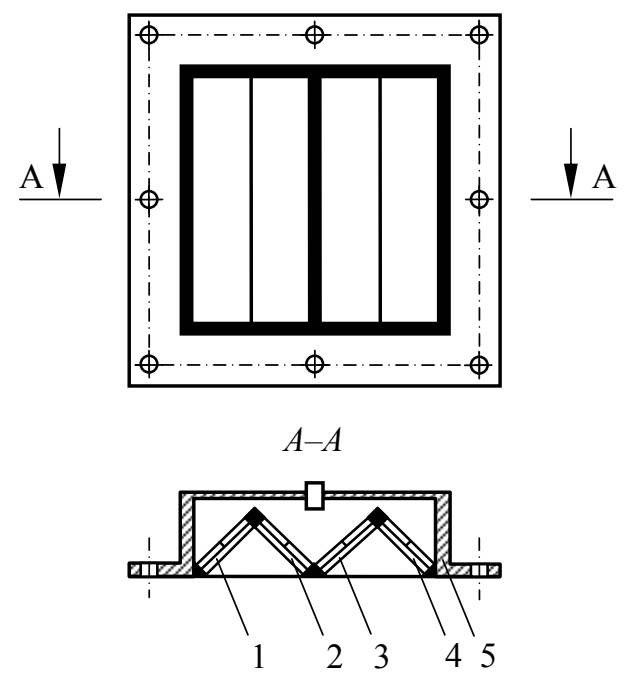

Fig.11. Unidirectional acoustic antenna, consisting of an array of four symmetrical bimorph piezoelectric ceramic transducers with loose edges and with parallel electric excitation: 1, 2, 3, 4 bimorph piezoelectric ceramic transducers; 5 - the encasement of the antenna

For the rectangular electro-acoustically active elements with loose edges (of the antenna presented in Fig. 11), the expression for calculating the radiation pattern is $[100]$ :

$$
D_{l s}=\frac{-4 l \cos \left(\frac{l}{2}\right) \sin m_{k}}{l^{2}-m_{l s}^{2}},
$$

where $m_{k}=k_{0}(\pi / 2) ; m_{l s}=k_{0} \pi ; k_{0}$ is the number of nodal lines of flexural vibration on the transducer's surface; $l$ is the width of the electro-acoustically active element.

For transducers with fixed edges, the expression for calculating the directivity pattern is [100]:

$$
D_{f s}=\frac{4 m_{0} \sin \left(\frac{l}{2}\right) \cos m_{k}}{m_{f s}^{2}-l^{2}},
$$

where $m_{f s}=\left(k_{0}-1\right) \pi$.

The actual image of this antenna is presented in Fig. 12.

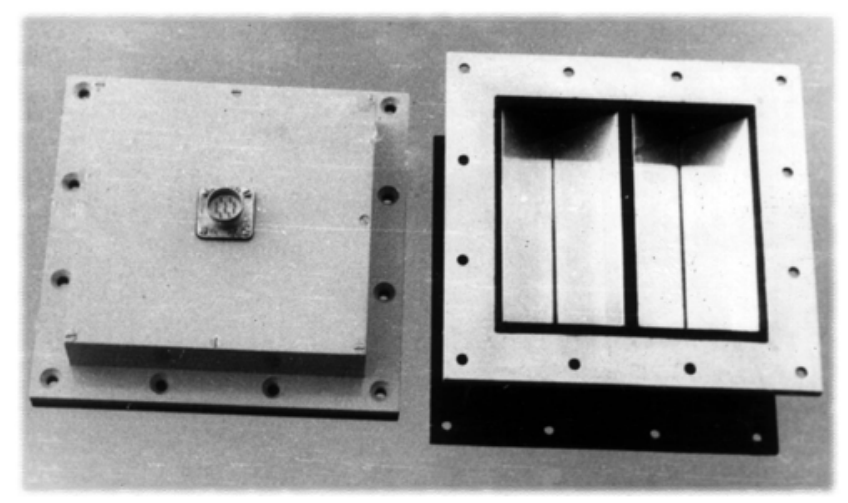

Fig.12. The actual image of the unidirectional acoustic antenna

Unidirectional radiation of the evaluated transducer in a flexural vibration is achieved by a relatively small increase in the physical measurements of the antenna [102]. The schematic diagram of such antenna is presented in Fig. 13.

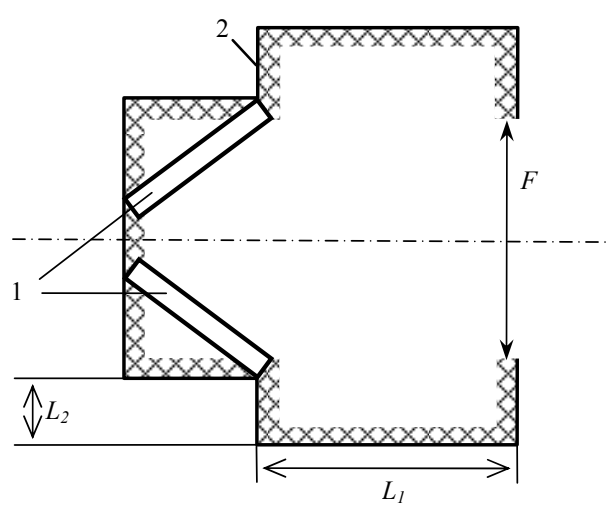

Fig. 13. Cross section of unidirectional acoustic antenna: 1 rectangular bimorph piezoelectric transducers; 2 - absorber of acoustic radiation

To achieve maximum radiation of the antenna, the vibrations of the transducers must be specially phased.

A paper [100] shows, that the near acoustic field zone of a bimorph in a flexural vibration is shorter than the near 
field zone produced by an oscillating piston. It is possible to use this property to eliminate peripheral radiation by using sound-absorbing elements (Fig. 14).

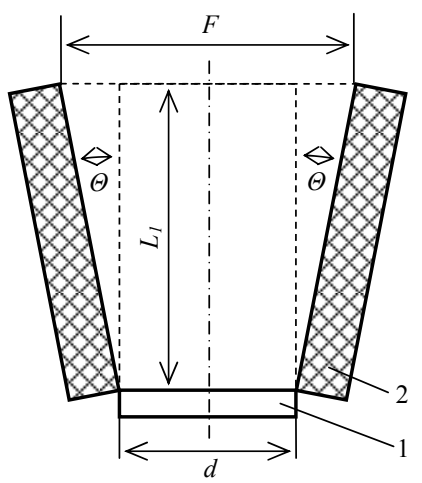

Fig. 14. Cross section of unidirectional acoustic antenna: $\mathbf{1}$ - bimorph piezoelectric unidirectional transducer (or an array of such transducers); 2 - absorber of acoustic radiation

The length $L_{l}$ of the absorber must meet the condition:

$$
L_{1}=(F / 2) \cdot \cot \Theta,
$$

where $\Theta$ is the angle between the maximum and the first minimum of the radiation pattern; $F$ is the aperture of the acoustic antenna.

In the antenna (Fig. 14) the absorber of acoustic radiation also serves as an element for matching acoustic impedances.

In Fig. 15, directivity patterns of the antenna (Fig. 13) are presented. The transducers were operating at the frequency of $17 \mathrm{kHz}$. In this case, the distance $L_{1}$ was $130 \mathrm{~mm}$ and the distance $L_{2}$ was $75 \mathrm{~mm}$. In Fig. 13 the construction elements of the reflector are made using Styrofoam.

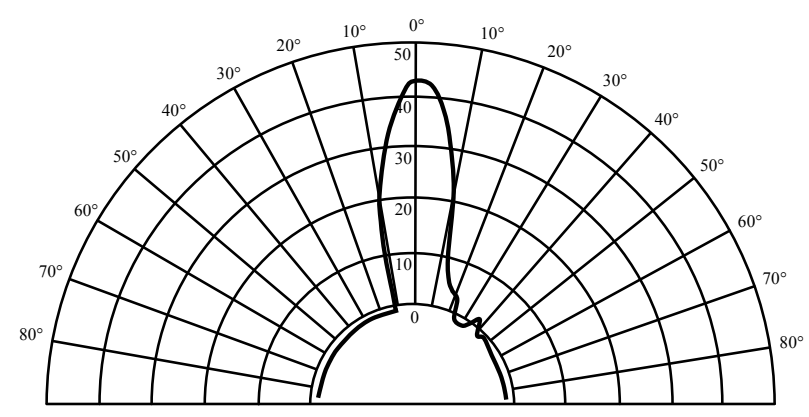

Fig. 15. Radiation pattern of the antenna (Fig. 13) with a Styrofoam absorber of acoustic waves

As seen from the experimentally measured radiation patterns of the antenna, only the main leaf of radiation pattern is transmitted through the aperture when the peripheral radiation is decrease. The peripheral radiation is damped by the construction elements.

\section{Conclusions}

Direct acoustic methods for determining porosity of materials can successfully be applied when designing automated control systems, because these methods are fast and provide a lot of information about the material. Lower ultrasonic frequencies are more suitable when implementing these methods, because the attenuation of such frequencies is lower in porous materials.

Since the direct acoustic measurement method is nondestructive, it can be successfully used as a real-time process control tool to investigate the textural properties and quality of bread products. This method can be recommended both for laboratory and industrial applications.

Indirect acoustic methods for determining porosity can be used in laboratory conditions, because they are faster when comparing them with mechanical measurement methods. When measuring the changes of the level of liquid by using an acoustic level meter, the sample remains submersed the whole time. This way, the dynamics of water absorption (penetration) process can be recorded.

When using an indirect acoustic method for measuring porosity, additional information about the defects of the surface of the porous material is obtained.

When combining acoustic distance meters for small distances with a special technological measurement equipment, they can be used to determine the porosity of materials. Therefore, such equipment can be used in research projects for the industry.

To measure accurately small distances using an echolocation-based distance meter, the measurement environment has to be controlled, because it is the main source of measurement errors.

The bimorph rectangular transducers with straight and parallel nodal lines of vibration can successfully be used when designing unidirectional acoustic antennas. The unidirectional radiation pattern of such antenna can be obtained by damping the peripheral radiation with construction elements.

Electro-acoustic transducers in a flexural vibration mode are a good choice when designing acoustic measurement devices for operation in gaseous (air) environments. By using bimorph piezoelectric ceramic transducers in a flexural vibration with elastic plates, it is possible to accurately measure small distances.

By arranging bimorph transducers at certain angles to one another, unidirectional radiation of energy by acoustic antennas is achieved. It is also possible to achieve unidirectional radiation by using reflectors of acoustic waves.

To decrease the peripheral radiation, electro-acoustic transducers in flexural vibration must have absorbers of acoustic waves with specific lengths and apertures.

The experimental results show that the measured radiation pattern of the transducer in a flexural vibration mode is similar to the calculated radiation pattern.

Transducers with flexural vibration could successfully be used when designing acoustic antennas for accurate measurements in a gas environment

Ultrasonic porosity evaluation methods can be successfully used for controlling the production processes, as well as for determining the porosity of materials in laboratory conditions. 


\section{References}

1. Keetels C.J. A.M., Van Vliet T., Walstra P. Relationship between the sponge structure of starch bread and its mechanical properties. Journal of Cereal Science. 1996. Vol. 24. P. 27-31.

2. Ponte Jr. J.G., Ovadia D.Z. Instrumental methods. In: R.E. Hebeda and H.F. Zobel, Editors, Baked goods freshness, Marcel Dekker, New York. 1996. P. 151-170.

3. Vincent J. F. V. Application of fracture mechanics to the texture of food. Engineering Failure Analysis. 2004. Vol. 11. P. 695-704.

4. Van Hecke E., Allaf K., Bouvier J. M. Texture and structure of crispy-puffed food products, mechanical properties in bending. Journal of Texture Studies. 1995. Vol. 26. P. 11-25.

5. Caballero P.A., Gomez M., Rosell C.M. Improvement of dough rheology, bread quality and bread shelf life by enzymes combination. Journal of Food Engineering. 2007. Vol. 81 (1). P. 42-53.

6. Biot M. A. Acoustics, elasticity and thermodynamics of porous media. Twenty-one papers by M.A. Acoustical Society of America. New York. 1992

7. Moraru C. I., Kokini J. L. Nucleation and expansion during extrusion and microwave heating of cereal foods. Comprehensive Reviews in Food Science and Food Safety. 2003. Vol. 2 (4). P. 147 165.

8. Garcia-Alvarez J., Rodriguez J.M., Yañez Y., Turo A., Chavez J. A., Garcia M. J., Salazar J. Study of the time-dependence of the mechanical properties of doughs for flour strength evaluation. Proceedings IEEE Ultrasonics Symposium. 2005. Vol. 3. P. 1480 1483.

9. Martini S., Herrera M. L., Marangoni A. G. New technologies to determine solid fat content on-line. Journal of the American Oil Chemists Society. 2005. Vol. 82. P. 313-317.

10. Rayleigh L. Theory of Sound (two volumes). New York: Dover Publications. 1987. Second edition. 1945 re-issue.

11. Gan T. H., Pallav P., Hutchins D. A. Non-contact ultrasonic quality measurements of food products. Journal of Food Engineering. 2006. Vol. 77 (2). P. 239-247.

12. Alava J. M., Sahi S. S., Garcia -Alvarez A., Turo A., Chavez J. A., Garcia M. J., Salazar J. Use of ultrasound for the determination of flour quality. Ultrasonics. 2007. Vol. 46 (3). P. 270-276.

13. Meyer S., Rajendram V. S., Povey M. J. W. Characterisation of reconstitudet milk powder by ultrasound spectroscopy. Journal of Food Quality. 2006. Vol. 29. P. 405-418.

14. Prakash M. N. K., Ramana K. V. R. Ultrasound and its application in the food industry. Journal of Food Science and Technology. 2003. Vol. 40 (6). P. 563-570.

15. Edmonds P. D. Ultrasonics, methods of experimental physics. Academic Press, New York. 1981. Vol. 19.

16. Povey M. J. W., Mason T. J. Ultrasound in Food Processing. London, England: Blackie Academic \& Professional. 1998.
17. Povey M. J. W., McClements D. J. Ultrasonics in food engineering. Part I: Introduction and experimental methods. Journal of Food Engineering. 1988. Vol. 8. P. 217-245.

18. Povey M. J. W., McClements D. J. Ultrasonics in food engineering. Part II: Applications. Journal of Food Engineering. 1989. Vol.9. P. 120

19. McClements D. J. Ultrasonic characterization of foods: principles methods and applications. CRC Critical Reviews in Food Science and Nutrition. 1997. Vol. 37. P. 1-46.

20. Povey M. J. W. Ultrasonics of foods. Contemporary Physics. 1998. Vol. 39. P. 467-478.

21. Buckin V., Kudryashov E., O'Driscoll B. High-resolution ultrasonic spectroscopy for material analysis. American Laboratory (Spectroscopy Perspectives Supplement). 28 March, 2002. P. 30-31.

22. Martini S. Ultrasonic spectroscopy in lipid food systems. Food Technology. 2007. Vol. 61 (2). P. 40-44.

23. Dukhin A. S., Goetz J. P., Wines T, H., Somasundaran $\mathbf{P}$ Acoustic and electro-acoustic Spectroscopy. Colloids and Surfaces. 2000. Vol. 173 (1-3). P. 127-159.

24. Dukhin A. S., Goetz J. P. New developments in acoustic and electro-acoustic spectroscopy for characterizing concentrated dispersions. Colloids and Surfaces. 2001. Vol. 192. P. 267-306.

25. Liebach W., Frense D., Nacke T., Beckmann D. Use of the ultrasound velocity measurement for the determination of the fat content in milk. (Nutzung der ultraschallgeschwindigkeitsmessung für die ermittlung des fettgehaltes in milch). Technisches Messen. 2005. Vol. 72 (10). P. 576-582.

26. Attenborough K. Acoustical characteristics of porous materials. Physics Reports. 1982. Vol. 82. P. 179-227.

27. Allard J. F. Propagation of sound in porous media: Modeling sound absorbing materials. Chapman \& Hall. London. 1993.

28. Allard J. F., Castagnède B., Henry M., Lauriks W. Evaluation of tortuosity in acoustic porous materials saturated by air. Review of Scientific Instruments. 1994. Vol. 65. P. 754-755

29. Champoux Y., Stinson M. R., Daigle G. Air-based system for the measurement of porosity. Journal of Acoustical Society of America. 1991. Vol. 89. P. 910-916.

30. Elmehdi H. M., Page J. H., Scanlon M. G. Using ultrasound to investigate the cellular structure of bread crumb. Journal of Cereal Science. 2003. Vol. 38. P. 33-42.

31. Papadakis E. P. Ultrasonic velocity and attenuation: Measurement methods with scientific and industrial applications. Physical Acoustics. 1976. Vol. 12. P. 277-374.

32. Povey M. J. W., Golding M., Higgs D., Wang Y. Ultrasonic spectroscopy studies of casein in water. International Dairy Journal. 1999. Vol. 9 (3-6). P. 299-303

33. Petrauskas A. Evaluation of porous food products by using ultrasonic methods. ISSN 1392-2114 Ultragarsas (Ultrasound). Kaunas: Technologija. 2007. Vol. 63. No. 3. P. 20-25. 
34. Petrauskas A. The application of the ultrasonic method for evaluating the porosity of bread. ISSN 1392-2114 Ultragarsas (Ultrasound). Kaunas: Technologija. 2010. Vol. 67. No. 3. P. 20-27.

35. Fellah Z. E. A., Berger S., Lauriks W., Depollier C., Aristegui C., Chapelon $\mathbf{J}-\mathbf{Y}$. Measuring the porosity and the tortuosity of porous materials via reflected waves at oblique incidence. Journal of Acoustical Society of America. 2003. Vol. 114. P. 2424-2432.

36. Kunigelis V., Senulis M. Acoustic investigation of air-filled porous materials. Acta Acustica united with Acustica. 2002. Vol. 88 (1). P. $14-18$.

37. Bernatovičiūtė R., Juodeikienė G. Non-destructive acoustic texture analysis of extruded cereals. Cereals - the Future Challenge: 50 years ISS-jubilee conference 1955-2005, Vienna, Austria, July 3-6, 2005: book of abstracts. Vienna: ICC. 2005. P. 63.

38. Bašinskienè L., Juodeikienė G. Texture analysis of cookies by acoustic method: A comparison to mechanical method. 12th ICC Cereal \& Bread Congress: Using Cereal Science and Technology for the Benefit of Consumers, 23-26 May, 2004, Harrogate. UK. Harrogate. 2004. P. 72

39. Juodeikienė G., Kunigèlis V., Vidmantienė D., Willem J. K. Acoustic screening method for the determination of deoxynivalenol (DON) in wheat. Veterinarija ir zootechnika, Lietuvos veterinarijos akademija. ISSN 1392-2130. Kaunas: Lietuvos veterinarijos akademija. 2004. Vol. 25 (47). P. 52-59.

40. Juodeikienė G., Bašinskienė L. Non-destructive texture analysis of cereal products. Food Research International. ISSN 0963-9969. Amsterdam: Elsevier. 2004. Vol. 37. No. 6. P. 603-610.

41. Nielsen M., Martens H. J. Low frequency ultrasonics for texture measurements in cooked carrots (Daucus carota L.). Journal of Food Science. 1997. Vol.62. No. 6. P. 1167-1175.

42. Martini S., Bertoli C., Herrera M. L., Neeson I., Marangoni A. G. Attenuation of ultrasonic waves: influence of microstructure and solid fat content. Journal of the American Oil Chemists Society. 2005. Vol. 82. P. 319-328.

43. Juodeikienė G., Vidmantienė D. Acoustic method for the quality of tea. Food science. ISSN 1002-6630. Beijing: Beijing Lica Food Co. Ltd. 2002. Vol. 23 (8). P. 230.

44. Juodeikienė G., Bašinskienė L., Vidmantienė D., Juodeikaitė E., Kunigèlis V. The application of the acoustic method in study of bread staling process and its inhibitors. Cereals 2000. Proceedings of the 11th ICC Cereal and Bread Congress and of 50th Australian Cereal Chemistry Conference. Cereal Chemistry Division, Royal Australian Chemical Institute. North Melbourne. Australia. 2001. ISBN 187689201 4. P. 73-76.

45. Fellah Z. E. A., Depollier, C., Berger, S., Lauriks, W., Trompette, P., Chapelon, J.-Y. Determination of transport parameters in airsaturated porous materials via reflected ultrasonic waves. Journal of the Acoustical Society of America. 2003. Vol. 114(5). P. 2561-2569.

46. Caviglia G., Morro A. A closed-form solution for reflection and transmission of transient waves in multilayers. Journal of the Acoustical Society of America. 2004. Vol. 116 (2). P. 643-654

47. Fellah Z. E. A., Berger S., Lauriks W., Depollier C., Fellah M. Measuring the porosity of porous materials having a rigid frame via reflected waves: A time domain analysis with fractional derivatives. Journal of Applied Physics. 2003. Vol. 93 (1). P. 296-303.
48. Mak D. K. Comparison of various methods for the measurement of reflection coefficient and ultrasonic attenuation. British Journal of Non-Destructive Testing. 1991. Vol. 33 (9). P. 441-449.

49. Castagnede B., Saeid M., Moussatov A., Tournat V. Reflection and transmission at normal incidence onto air-saturated porous materials and direct measurements based on parametric demodulated ultrasonic waves. Ultrasonics. 2006. Vol. 44 (2). P. 221-229.

50. Pactrick N. Plane acoustic waves in linear viscoelastic porous media. J. Aconst. Soc. Am. 1991. Vol. 89 (4). P. 1532-1550.

51. Elmehdi H.M., Page J.H., Scanlon M.G. Using ultrasound to investigate the cellular structure of bread crumb. Journal of Cereal Science 2003. Vol. 38. P. 33-42.

52. Fellah Z.E.A., Berger S., Lauriks W., Depollier C., Aristegui C., Chapelon J-Y. Measuring the porosity and the tortuosity of porous materials via reflected waves at oblique incidence. Journal of Acoustical Society of America. 2003. Vol. 114. P. 2424-2432.

53. Lafarge D., Lemarinier P., Allard J.F., Tarnow V. Dynamic compressibility of air in porous structures at audible frequencies, Journal of the Acoustical Society of America. 1997. Vol. 102. P. 1995-2006.

54. Lagrain B., Boeckx L., Wilderjans E., Delcour J.A., Lauriks W. Non-contact ultrasound characterization of bread crumb: application of the Biot-Allard model, Food Research International. 2006. Vol. 39(10). P. 1067-1075.

55. Pallav P., Hutchins D., Yin X. Air-coupled ultrasonic spectroscopy of highly damping materials using pulse compression $\mathrm{n}$ Transaction on Ultrasonics, Ferroelectric, and Frequency Control. 2009. Vol. 56(6). P. 1207

56. Gómez Álvarez-Arenas T.E. A non-destructive integrity test for membrane glitters based on air-coupled ultrasonic spectroscopy. IEEE Transactions on Ultrasonics, Ferroelectrics, and Frequency Control. 2003. Vol. 50 (6). P. 676-685.

57. Álvarez-Arenas T.E.G., González B., Apel P.Yu., Orelovitch O.L., Mitrofanov A.V. Ultrasound propagation in the micropores of track membranes. Applied Physics Letters. 2005. Vol. 87 (11). P. 13.

58. Berriman J. R., Hutchins D. A., Neild A., Gan T. H., Purnell P. The application of time-frequency analysis to the air-coupled ultrasonic testing of concrete, IEEE Trans. Ultrason. Ferroelectr. Freq. Control. 2006. Vol. 53 (4). P. 768-776.

59. P. Pallav, D.A. Hutchins, T.H Gan. Air-coupled ultrasonic evaluation of food materials. Ultrasonics. 2009. Vol. 49 (2). P. 244 253.

60. Zhao B., Jiang Y., Basir O.A., Mittal G.S. Foreign body detection in foods using the ultrasound pulse-echo method. Journal of Food Quality. 2004. Vol. 27. P. 274-288.

61. Cho B.K., Irudayaraj J.M.K. Foreign object and internal disorder detection in food material using non-contact ultrasound imaging. Journal of Food Science. 2003. Vol. 68 (3). P. 967-974.

62. Gan T.H., Pallav P. and Hutchins D.A. Non-contact ultrasonic measurements of food products. Journal of Food Engineering. 2006. Vol. 77. P. 239-247. 
63. Juodeikienė G., Petrauskas A., Jakubauskienė L., Minialga V. Development of an indirect method for evaluating porous cereal product structures using acoustic echolocation. Meas. Sci. Technol. 2006. Vol. 17 (2). P. 249-256.

64. Minialga V., Petrauskas A., Jakubauskienė L. Development of ultrasonic method for quality estimation of porous products. ISSN 1392-2114 Ultragarsas (Ultrasound). Kaunas: Technologija. 1999. Vol. 1 (31). P. 25-27.

65. Minialga V., Petrauskas A. Investigation of porous structures by indirect ultrasonic method. Advanced materials and technologies: book of abstracts of the 6-th International summer school-conference, Palanga, Lithuania, 27-31 August 2004. ISBN 9955-09-681-0. Kaunas: Technologija. 2004. P. 82.

66. Petrauskas A., Juodeikienė G., Bašinskienė L., Jakubauskienė L. The usage of acoustical methods for investigation of texture of food stuffs. ISSN 1392-2114 Ultragarsas (Ultrasound). Kaunas: Technologija. 1996. Vol. 1 (26). P. 29-32.

67. Minialga V., Petrauskas A. Acoustic echolocation method for evaluation of corrosion and porosity of materials. Integral des communications unabridged edition Congress Cofrend Controles non Destructives CND and Corrosion, Reims. 24-26 April 2001. P. 1-6.

68. Minialga V., Petrauskas A. The acoustic methods for investigation of porous and foam materials. ISSN 1392-2114 Ultragarsas (Ultrasound). Kaunas: Technologija. 2002. Vol. 3 (44). P. 37-44.

69. Minialga V., Petrauskas A., Razutis P. Results of measurement of liquid absorption in porous materials by ultrasonic method. ISSN 1392-2114. Ultragarsas (Ultrasound). Kaunas: Technologija. 2000. Vol. 1 (34). P. 31-33.

70. Bernatovičiūtė R., Juodeikienè G., Minialga V., Petrauskas A. Development of complex investigation of extrudats using acoustic echolocation method. ISSN 1392-2114. Ultragarsas (Ultrasound). Kaunas: Technologija. 2007. Vol. 2 (62). P. 11-16.

71. Billy M. and al. Measurements of backscatered leaky Lamb waves in plates // J.acoust.soc.Amer. 1984. V.75. N.3. P. 996-1001.

72. Викторов И. Физические основы применения ультразвуковых волн Рэлея и Лэмба в технике. М.: Наука. 1966.С.167.

73. Викторов И. Типы звуковых поверхностных волн в твердых телах. Акустический журнал. 1979. Т.25. Вып.1. С.1-17.

74. Deighton M. et. al. Mode conversion of Rayleight and Lamb wave to compression waves at a metal-liquid interface. Ultrasonics. 1981. V.19. N.6. P. 249.258

75. Dayal V., Kinra V. Leaky Lamb waves in an anisatropic plate. J. Acoust. Soc. Amer. 1989. V.85. N.6. P. 2268-2276.

76. Меркулов Л. Затухание нормальных волн в пластинах, находящихся в жидкости. Акустический журнал. 1964. Т.10. Вып.2. С. 206-212.

77. Vrba J. Haering R. P. Elastic waves in free plates Acoustic Soc Amer. 1975. V.57. N.1. P.116-119.

78. Wu J., Zhu Z. The propagation of Lamb waves in aplate bordered with layers of a liquid. J. Acoust. Soc. Am. 1992. Vol.91 (2). P.861867.
79. Petrauskas A. Increasing the accuracy of measurement for the smallshift, two-channel ultrasonic echolocation-based distance meter. ISSN 1392-2114 Ultragarsas (Ultrasound). Kaunas: Technologija. 2010. Vol. 65. No. 2. P. 13-16.

80. Petrauskas A., Razutis P. Investigation of echolocational ultrasonic methods by increasing accuracy in level measurements. ISSN 1392 2114. Ultragarsas (Ultrasound). Kaunas: Technologija. 2001. Nr. 4 (41). P. 18-21.

81. Xian X., Lin S. Study on the compound multifrequency ultrasonic transducer in flexural vibration. Ultrasonics. 2008. Vol. 48. No.3. P.202-208.

82. Babic M. A $200-\mathrm{kHz}$ ultrasonic transducer coupled to the air with a radiating membrane. Ultrasonics, ferroelectrics and frequency control. IEEE Transactions. 1991. Vol.38. P.252 - 255.

83. Yamane H., Kawamura M. Sound sources with vibration plates in flexural modes and reflection plates for airborne ultrasonics. J. Acoust. Soc. Japan. 1976. Vol. 32. No.2. P.83-91.

84. Bindal V. and Chandra M. An improved piezoelektric ceramic transducer for ultrasonic applications in air. Archives of acoustics. 1982. Vol. 7. No.3-4. P. 281-286.

85. Honda Y., Matsuhisa H. and Sato S. Radiation efficiency of a baffled circular plate in flexural vibration. Journal of sound and vibration. 1983. Vol.88. No. 4. P. 437-446.

86. Barone A., Gallego-Juarez J A. Flexural vibrating free-edge plates with stepped thickness for generating high directional ultrasonic radiation. JASA. 1972. Vol.51. No.3. P.953-959.

87. Germano C. P. Flexure mode piezoelectric transducers. IEEE Transactions on audio and electroacoustics. 1971. Vol. AU-19. No.1. P.6-12

88. Matsuzava K. Sound sources for producing intense ultrasonic fields in small regions in air. - In: Eighth International Congress on Acoustics. London. 1974. Vol.11. P.709.

89. Petrauskas A. Investigation and construction of measuring transducers for ultrasonic devices using flexural vibrations (in Russian). Ph. D. thesis. Kaunas. 1975. P. 147.

90. Petrauskas A. The optimization of directional characteristics for acustic antennas from piezoceramic rectangular bimorph transducers in flexural vibration. ISSN 1392 - 2114. Ultragarsas (Ultrasound). Kaunas: Technologija. 2007. Nr 1(62). P. 26-32.

91. Petrauskas. A. Design and the radiation patterns of rectangular symmetric bimorph piezoelectric transducers in cosinusoidal flexural vibration. ISSN 1392 - 2114. Ultragarsas (Ultrasound). Kaunas: Technologija. 2009. Nr.1(64). P. 29-36.

92. Petrauskas A. A study of the design and the radiation patterns of rectangular bimorph acoustic transducers with thin piezoelectric ceramic plates. ISSN 1392 - 2114. Ultragarsas (Ultrasound). Kaunas: Technologija. 2008. Nr.4(63), P.57-65.

93. Kaya O., Sahin A., Kaleci D. Pressure field of rectangular transducers at finite amplitude in three dimensions. Ultrasound in Medicine \& Biology. 2006.Vol. 32, Issue 2. P. 271-280. 
94. Minialga V., Petrauskas A. Estimation of directivity patterns of two rectangular acoustic radiators oriented at various angles. ISSN $1392-$ 2114 Ultragarsas (Ultrasound). Kaunas: Technologija. 1998. Nr. 1(29). P. 20-23.

95. Ruzzene M. Vibration and sound radiation of sandwich beams with honeycomb truss core. Journal of Sound and Vibration. 2004. 277 (45). P. 741-763. doi: 10.1016/j.jsv.2003.09.026.

96. Sorokin S. V. Vibrations of and sound radiation from sandwich plates in heavy fluid loading conditions Composite Structures. 2000. 48. (4). P.219-230. doi:10.1016/S0263-8223(99)00103-8.

97. Farag N. H., Pan J. Free and forced in-plane vibration of rectangular plates. Journal of the Acoustical Society of America. 1998. 103 (1). P. 408-413.

98. Lin S. Piezoelectric ceramic rectangular transducers in flexural vibration. IEEE Transactions on Ultrasonics, Ferroelectrics, and Frequency Control 2004. 51 (7). P. 865-870

99. Lin S. Study on the Langevin piezoelectric ceramic ultrasonic transducer of longitudinal-flexural composite vibrational mode. Yadian Yu Shengguang/Piezoelectrics and Acoustooptics. 2005. 27 (6). P. 620-623.

100. Petrauskas A. A study of the design and the radiation patterns of rectangular bimorph acoustic transducers with thin piezoelectric ceramic plates. ISSN 1392-2114 Ultragarsas (Ultrasound). Kaunas: Technologija. 2008. Vol. 63. No. 4. P. 57-65.
01. Petrauskas A. The design and the radiation patterns of rectangular symmetric bimorph piezoelectric transducers in cosinusoidal flexural vibration. ISSN 1392-2114 Ultragarsas (Ultrasound). Kaunas: Technologija. 2009. Vol. 64. No. 1. P. 29-36.

102. Petrauskas A. The calculation of near and far fields for acoustic antennas consisting of piezoelectric rectangular bimorph transducers in flexural vibration. ISSN 1392-2114 Ultragarsas (Ultrasound). Kaunas: Technologija. 2010. Vol. 65. No. 1. P. 19-24.

A. Petrauskas, D. Petrauskas

Poringų medžiagų ịvertinimas ultragarsiniais metodais

Reziumè

Apžvelgtos galimybès taikyti ivairius metodus poringoms struktūroms tirti ir ịvertinti. Pabrèžta, kad ultragarsiniai virpesiai ir bangos dẻl savo fizinių savybių ir plataus darbinių dažnių intervalo yra tinkami poringoms struktūroms tirti ir turi nemažai pranašumų, palyginti su kitais metodais. Pasiūlyta akustini aidolokacini metodą taikyti poringoms struktūroms tirti tiesiogiai ir netiesiogiai. Pagristas teiginys, kad akustinis aidolokacinis metodas suteikia kompleksinę informaciją apie poringu medžiagu struktūra ir gali būti rekomenduojamas taikyti praktikoje - aukštos kokybès produktams gauti, juos suskirstyti i rūšis pagal kokybę. Aptartos galimybès Lembo bangas naudoti poringoms struktūroms ivertinti, ultragarsini aidolokacini matavimo metoda taikyti poringoms struktūros tyrinèti. Pateikti akustinių metodų, taikomų sudètingoms poringoms struktūroms tyrinèti, principai ir matavimo schemos. Aprašytos akustiniu antenu su vienlape kryptine charakteristika konstrukcijos, naudotinos akustinès analizès prietaisuose. Pateikta praktine stačiakampiu bimorfiniu pjezokeraminiu keitikliu su laisvais ir itvirtintais kraštais išraiška spinduliavimo kryptinėms charakteristikoms apskaičiuoti. Straipsnis gali būti naudingas poringų struktūrų tyrèjams.

Pateikta spaudai 20111212 